\title{
KERENTANAN BERAS ASAL PADI LOKAL DATARAN TINGGI ACEH TERHADAP HAMA PASCAPANEN Sitophilus oryzae L. (COLEOPTERA: CURCULIONIDAE)
}

\author{
(Susceptibility Rice from Paddy Local Upland Aceh to Pest Postharvest Sitophilus oryzae L. \\ (Coleoptera: Curculionidae))
}

\author{
HENDRIVAL HENDRIVAL, KHAIDIR KHAIDIR, AULIA AFZAL DAN RAHMANIAH RAHMANIAH
}

\author{
Program Studi Agroekoteknologi, Fakultas Pertanian, Universitas Malikussaleh \\ Jalan Banda Aceh-Medan, Kampus Utama Reuleut, \\ Kecamatan Muara Batu, Kabupaten Aceh Utara 24355 \\ email: hendrival@unimal.ac.id HP: 081360038391
}

\begin{abstract}
The selection rice of susceptibility to pests $S$. oryzae can be done through the utilization of local paddy germplasm. The study aims to determine the level susceptibility of local upland rice Aceh to against pest attack S. oryzae. The results showed that the local paddy rice from upland Aceh has a level resistance from resistance until moderately to susceptible to pest infestations $S$. oryzae. The rice Depet classified in the category-resistant, while Putih, Toa, and Bontok classified in the moderate category. Local rice upland Aceh from Pulo Aceh and Tajuk classified in the category of moderate to susceptible to pest attack S. oryzae during storage rice. Results of correlation analysis showed that resistance rice local upland Aceh affected by moisture content $\left(r=0.864^{*} ; P<0.05\right)$. Results of correlation analysis showed that positive correlation non significant between resistance with characteristic dimensions of rice such as length $(r=0.106 ; P>0.01)$, negative correlation non significant with wide $(r=-0.339 ; P>0.01)$, and a positive correlation non significant with ratio $(r=$ $0.167 ; P>0.01)$. The content of protein and moisture content of the rice had a positive correlation with the population of adult $S$. oryzae (moisture content: $r=0.928^{* *}$; protein: $r=0.884^{* *} P<0.01$ ), the percentage of perforated rice (moisture content: $r=0.872^{*} P<0.05$; protein: $r=0.945^{\star *} P<0.01$ ), and the percentage of rice powder (moisture content: $r=0.912^{* *}$; protein: $r=0.951^{* *} P<0.01$ ) during storage.
\end{abstract}

Keywords: Susceptibility, Sitophilus oryzae, rice upland Aceh, susceptibility index

\section{PENDAHULUAN}

Beras merupakan komoditas penting di Indonesia, karena merupakan makanan pokok sebagian besar penduduk Indonesia, termasuk di Provinsi Aceh. Kerusakan beras selama penyimpanan yang disebabkan oleh hama pascapanen menjadi salah satu masalah di Indonesia. kerusakan beras selama penyimpanan meliputi penurunan bobot dan kontaminasi beras dari kotoran serta penurunan kandungan nutrisi beras. Berbagai jenis serangga hama pascapanen yang menyerang beras di Indonesia yaitu Sitophilus oryzae, S. zeamais, Corcyra cephalonica, Plodia interpunctella, Ephestia elutella, Cryptolestes ferrugineus, Oryzaephilus surinamensis (Kalshoven, 1981; Anggara \& Sudarmaji, 2008). Hama S. oryzae atau kumbang bubuk beras merupakan hama primer pada komoditas pertanian dari biji-bijian dan banyak ditemukan di negara-negara Asia (Zunjare et al., 2016). S. oryzae tergolong sebagai serangga polifag yang merusak beras, sorgum, gandum, dan jagung di penyimpanan (Longstaff, 1981). Penggunaan insektisida untuk mengendalikan hama $S$. oryzae bukan pilihan yang layak untuk dilakukan oleh petani di Indonesia, karena menambah biaya budidaya. Selain itu, penggunaan insektisida dapat meningkatkan residu kimia pada beras, efek berbahaya pada organisme bukan sasaran, dan terjadinya resistensi pada hama pascapanen terhadap insektisida (Adarkwah et al., 2012; Nesci et al., 2011).

Salah satu cara untuk mengurangi kerusakan beras saat penyimpanan yaitu menyimpan beras yang memiliki sifat ketahanan terhadap serangan $S$. oryzae. Penggunaan varietas tahan merupakan komponen penting dalam strategi pengendalian hama terpadu dalam rangka menekan kehilangan hasil pada saat pascapanen (Bergvinson \& Garcia-Lara, 2004), sehingga memberikan solusi praktis dalam meminimalkan kerusakan akibat hama S. oryzae, seperti hemat biaya, berkelanjutan, dan ramah lingkungan (Derera et al., 2014; 
Zakka et al., 2015). Aksesi-aksesi padi lokal Aceh masih banyak digunakan oleh petani di berbagai kabupaten di Provinsi Aceh, termasuk di daerah dataran tinggi Aceh. Hingga saat ini, plasma nutfah padi dataran tinggi Aceh masih belum teridentifikasi dan dievaluasi, terutama tentang ketahanannya terhadap serangan hama pascapanen $S$. oryzae. Hasil penelitian Gbaye \& Olanrewaju (2016) menunjukkan bahwa beras dari dataran tinggi Nigeria memiliki ketahanan terhadap serangan S. oryzae. Kajian yang sama juga berpeluang untuk dikembangkan pada komoditas padi lokal dataran tinggi Aceh sehingga informasi yang diperoleh dapat digunakan sebagai rekomendasi bagi petani untuk lebih banyak membudidayakan padi lokal yang relatif tahan terhadap serangan hama $S$. oryzae ataupun sumber informasi bagi pemulia tanaman untuk merakit varietas padi yang tahan terhadap serangan hama $S$. oryzae. Penelitian bertujuan untuk mengetahui tingkat kerentanan beras asal padi lokal dataran tinggi Aceh terhadap serangan hama S. oryzae.

\section{BAHAN DAN METODE}

Penelitian dilaksanakan di Laboratorium Hama dan Penyakit Tanaman, Program Studi Agroekoteknologi, Fakultas Pertanian Universitas Malikussaleh. Waktu pelaksanaan penelitian dimulai dari bulan Agustus sampai November 2016. Kegiatan ekplorasi dan koleksi plasma nutfah padi lokal dataran tinggi Aceh dilakukan dengan cara survei ke sentrasentra penanaman padi di Kabupaten Aceh Tengah dan Bener Meriah Propinsi Aceh untuk mendapatkan plasma nutfah padi lokal yang ditanam oleh petani. Padi yang diperoleh dari petani diberikan lebel nama daerah dan dibawa ke Laboratorium Hama dan Penyakit Tanaman untuk keperluan penelitian.

Pembiakan dan infestasi S. oryzae. Tujuan pembiakan $S$. oryzae yaitu untuk memperoleh imago $S$. oryzae dalam jumlah yang banyak dan umur yang seragam. Pembiakkan serangga $S$. oryzae dilakukan pada stoples dengan kapasitas $0,5 \mathrm{~kg}$ yang berisikan beras merah sebanyak $250 \mathrm{~g}$. Imago $S$. oryzae yang diperoleh dari gudang penyimpanan padi diinfestasikan ke dalam stoples pemeliharaan dengan tingkat populasi 40 pasang imago $S$. oryzae dengan $250 \mathrm{~g}$ beras merah. Stoplesstoples pemeliharaan serangga dilengkapi dengan tutup yang dilubangi dan diberi kain kasa untuk aerasi. Stoples-stoples pemeliharaan yang telah berisi serangga $S$. oryzae dan pakan diletakkan pada ruangan pemeliharaan di laboratorium. Pembiakan $S$. oryzae dilakukan selama empat minggu sesuai dengan siklus hidup S. oryzae dari peletakkan telur hingga keluarnya imago. Pengayakan beras dilakukan untuk memisahkan 40 pasang imago $S$. oryzae dari media beras, setelah masa infestasi selesai dilakukan. Media beras tersebut diinkubasikan kembali sampai muncul imago S. oryzae. Imago-imago S. oryzae tersebut disimpan pada media beras yang baru. Pengayakan dilakukan secara berulang setiap hari hingga didapatkan jumlah imago $S$. oryzae dengan umur yang diketahui. Imago $S$. oryzae yang digunakan untuk penelitian telah berumur $7-15$ hari karena telah mencapai kedewasaan kawin dan dapat memproduksi telur secara maksimal. Setiap jenis beras yang digunakan dalam penelitian sebanyak $250 \mathrm{~g}$ dimasukkan ke dalam stoples plastik dengan ukuran tinggi $12 \mathrm{~cm}$ dan diameter $15 \mathrm{~cm}$. Pada tutup stoples plastik diberi lubang aerasi yang dilapisi kain kasa. Imago $S$. oryzae dari hasil pembiakan diinfestasikan dengan tingkat populasi awal yaitu 10 pasang imago $S$. oryzae ke dalam $250 \mathrm{~g}$ beras dan disimpan selama penelitian.

Populasi Imago S. oryzae. Populasi imago S. oryzae diamati pada 36 sampai 85 hari setelah infestasi. Pengamatan populasi dilakukan dengan menghitung jumlah imago $S$. oryzae dari setiap perlakuan jenis beras. Beras dalam stoples plastik terlebih dahulu diaduk hingga diperkirakan imago $S$. oryzae terdistribusi secara merata di dalam stoples.

Kerusakan beras. Penentuan kerusakan beras melalui parameter persentase beras berlubang dan persentase bubuk beras. Persentase beras berlubang merupakan salah satu parameter dalam melihat tingkat kerusakan beras akibat aktivitas makan dari $S$. oryzae. Penghitungan beras berlubang beras selama penelitian dilakukan pada sampel beras sebanyak 100 butir beras. Beras dalam wadah penelitian terlebih dahulu diaduk hingga beras utuh dan beras berlubang terdistribusi secara merata di dalam wadah penelitian. Persentase beras berlubang dihitung dengan rumus yaitu persentase beras berlubang = (jumlah beras berlubang/jumlah sampel beras) x $100 \%$.

Bubuk merupakan beras yang sudah mengalami kerusakan atau berlubang akibat dari aktivitas makan $S$. oryzae pada beras tersebut. Untuk menghitung bubuk dari beras yang rusak, masing-masing beras dalam wadah penelitian diayak dengan saringan untuk memisahkan antara beras dan bubuk. Penghitungan persentase bubuk beras dilakukan pada akhir penelitian. Penghitungan persentase beras bubuk menggunakan rumus 
berikut persentase bubuk beras $=$ (berat bubuk

beras/berat beras awal) $\times 100 \%$.

Tabel 1. Dimensi dan sifat kimia beras dari padi lokal dataran tinggi Aceh

\begin{tabular}{|c|c|c|c|c|c|c|c|c|c|}
\hline \multirow[b]{2}{*}{ Jenis beras } & \multicolumn{3}{|c|}{ Dimensi beras } & \multicolumn{6}{|c|}{ Sifat kimia beras } \\
\hline & $\begin{array}{l}\text { Panjang } \\
\text { (mm) }\end{array}$ & $\begin{array}{l}\text { Lebar } \\
(\mathrm{mm})\end{array}$ & $\begin{array}{c}\text { Bentuk } \\
\text { butiran } \\
\text { beras }\end{array}$ & $\begin{array}{l}\text { Kadar } \\
\text { air }\end{array}$ & $\begin{array}{l}\text { Kadar } \\
\text { abu }\end{array}$ & Lemak & Protein & Serat & Karbohidrat \\
\hline Putih & $\begin{array}{c}7,23 \\
\text { (panjang) }\end{array}$ & 2,17 & $\begin{array}{c}3,33 \\
\text { (ramping) }\end{array}$ & 9,430 & 1,278 & 0,406 & 0,440 & 1,806 & 86,641 \\
\hline Tajuk & $\begin{array}{c}7,21 \\
\text { (panjang) }\end{array}$ & 2,12 & $\begin{array}{c}3,40 \\
\text { (ramping) }\end{array}$ & 10,920 & 1,207 & 0,509 & 0,926 & 1,710 & 84,728 \\
\hline Bontok & $\begin{array}{c}6,10 \\
\text { (sedang) }\end{array}$ & 2,25 & $\begin{array}{c}2,71 \\
\text { (sedang) }\end{array}$ & 10,370 & 1,316 & 0,543 & 0,555 & 3,447 & 83,768 \\
\hline Depet & $\begin{array}{c}5,96 \\
\text { (sedang) }\end{array}$ & 2,18 & $\begin{array}{c}2,73 \\
\text { (sedang) }\end{array}$ & 9,300 & 0,981 & 0,572 & 0,408 & 3,605 & 85,135 \\
\hline Pulo Aceh & $\begin{array}{c}7,09 \\
\text { (panjang) }\end{array}$ & 2,10 & $\begin{array}{c}3,38 \\
\text { (ramping) }\end{array}$ & 10,930 & 1,163 & 0,781 & 1,563 & 3,004 & 82,559 \\
\hline Toa & $\begin{array}{c}4,15 \\
\text { (pendek) }\end{array}$ & 2,05 & $\begin{array}{c}2,02 \\
\text { (agak bulat) }\end{array}$ & 10,520 & 0,960 & 0,234 & 0,681 & 2,550 & 85,056 \\
\hline
\end{tabular}

Analisis dimensi dan kimia beras. Analisis dimensi beras meliputi ukuran panjang, lebar, rasio panjang dan lebar. Pengukuran panjang butiran beras dilakukan diantara dua ujung butiran beras utuh. Untuk pengukuran lebar butiran beras dilakukan diantara punggung dan perut beras utuh. Pengukuran panjang dan lebar butiran beras menggunakan jangka sorong. Penentuan ukuran panjang dan lebar butiran beras dilakukan dengan mengambil secara acak 20 butir beras utuh. Pengukuran panjang dan lebar butiran beras dinyatakan dalam satuan $\mathrm{mm}$. Berdasarkan ukuran panjang butiran beras, beras dikelompokkan menjadi beras sangat panjang $(>7,5 \mathrm{~mm})$, panjang $(6,6-7,50 \mathrm{~mm})$, sedang $(5,51-6,60$ $\mathrm{mm})$, dan pendek $(<5,5 \mathrm{~mm})$. Bentuk butiran beras ditentukan dengan menghitung nilai rasio panjang dan lebar butiran beras. Bentuk butiran beras dikelompokkan menjadi ramping $(>3,0)$, sedang $(2,1-3,0)$, agak bulat $(1,1-2,0)$, dan bulat $(<1,1)$ (Indrasari et al., 2008). Analisis proksimat dilakukan untuk mengetahui kandungan kimia dari beras meliputi kadar air, abu, protein, lemak, serat, dan karbohidrat. Analisis proksimat pada beras berdasarkan AOAC (2005). Hasil pengukuran dimensi dan kimia beras disajikan pada Tabel 1 .

Penentuan indeks kerentanan. Indeks kerentanan ditentukan berdasarkan median waktu perkembangan dan jumlah F1. Median waktu perkembangan adalah lamanya waktu yang diperlukan hingga munculnya $50 \%$ atau separuh dari total turunan pertama mencapai imago. Jumlah $\mathrm{F} 1 \mathrm{~S}$. oryzae pada beras ditentukan setelah beras dan imago $S$. oryzae diinkubasi selama 30 hari, imago yang muncul pada $31 \mathrm{HSI}$ dikeluarkan dari wadah penelitian dan dihitung setiap harinya hingga 50 hari dengan asumsi imago turunan pertama telah muncul secara keseluruhan. Median waktu perkembangan dan jumlah $\mathrm{F} 1$ merupakan parameter yang penting untuk menentukan ketahanan beras dari plasma nutfah padi lokal dataran tinggi Aceh terhadap $S$. oryzae. Pengelompokan tingkat kerentanan beras dari plasma nutfah padi lokal terhadap infestasi $S$. oryzae berdasarkan nilai indeks kerentanan yaitu katagori resisten (indeks kerentanan berkisar antara 0-3), moderat (indeks kerentanan berkisar antara 4-7), rentan (indeks kerentanan berkisar antara 8-10), dan sangat rentan (indeks kerentanan $>11$ ). Indeks kerentanan dihitung menggunakan rumus Dobie (1974) yaitu.

$$
\text { Indeks kerentanan }=100 \times \frac{\left(\log _{\mathrm{e}} F\right)}{D}
$$

Keterangan:

$\mathrm{F}=$ jumlah $\mathrm{F} 1 \mathrm{~S}$. oryzae yang muncul

$D=$ median waktu perkembangan

Analisis data. Penelitian dilaksanakan dalam bentuk percobaan laboratorium dengan satu jenis perlakuan yang disusun dalam Rancangan Acak Lengkap dengan perlakuan yaitu jenis beras dari padi lokal dataran tinggi Aceh yang terdiri dari Tajuk, Putih, Pulo Aceh, Toa, Depet, dan Bontok. Setiap perlakuan diulang sebanyak tiga kali sehingga terdapat 18 percobaan. Data hasil pengamatan dianalisis dengan analisis ragam. Untuk membandingkan rata-rata perlakuan menggunakan uji DMRT taraf 0,05. Untuk mengukur kekuatan hubungan antara indeks kerentanan beras terhadap dimensi beras, sifat kimia beras, populasi, median waktu perkembangan $S$. oryzae, persentase beras berlubang, dan persentase bubuk beras ditentukan dengan analisis korelasi.

\section{HASIL DAN PEMBAHASAN Populasi Imago S. Oryzae}

Hasil analisis ragam menunjukkan bahwa jenis beras asal dataran tinggi Aceh berpengaruh sangat nyata terhadap populasi 
imago $S$. oryzae (populasi imago $36 \mathrm{HSI}: F=$ 8,41 dan $P<0,0013$; populasi imago $43 \mathrm{HSI}$ : $F=16,38$ dan $P<0,0001$; populasi imago 50 HSI: $F=7,40$ dan $P<0,0022$; populasi imago $57 \mathrm{HSI}: F=9,34$ dan $P<0,0008$; populasi imago $64 \mathrm{HSI}: F=11,36$ dan $P<0,0003$; populasi imago $71 \mathrm{HSI}: F=16,96$ dan $P<$ 0,0001 ; populasi imago $78 \mathrm{HSI}: F=20,54$ dan $P<0,0001$; serta populasi imago $85 \mathrm{HSI}: F=$ 19,63 dan $P<0,0001$ ). Populasi imago $S$. oryzae paling tinggi dijumpai pada beras Pulo Aceh, Tajuk, dan Toa. Populasi S. oryzae pada beras Pulo Aceh berkisar antara 36$680,33 \mathrm{imago} / 250 \mathrm{~g}$, sedangkan pada beras Tajuk berkisar antara 43,67-434,33 imago/250 g. Populasi $S$. oryzae pada beras Toa mencapai 63,33-232,67 imago/250 g. Populasi S. oryzae paling rendah dijumpai pada beras Depet berkisar antara 22-47 imago/250 g. Populasi S. oryzae pada Putih dan Bontok berkisar antara 31,67-127,33 dan 36,33-223 imago/250 g. Hasil penelitian menunjukkan beras ulo Aceh, Tajuk, dan Toa merupakan jenis makanan yang paling disukai oleh $S$. oryzae dibandingkan dengan beras Bontok, Putih, dan Depet (Tabel 2).

Perbedaan jenis beras asal padi lokal dataran tinggi Aceh dapat mempengaruhi pertumbuhan populasi $S$. oryzae. Hama $S$. oryzae memiliki tingkat preferensi yang tinggi pada beras Pulo Aceh, Tajuk, dan Toa dibandingkan pada beras Bontok, Putih, dan Depet. Peningkatan jumlah populasi $S$. oryzae berkaitan dengan kualitas beras yang dikonsumsi. Kecenderungan hama dalam memilih makanan dipengaruhi oleh kandungan nutrisi, kadar air, warna dan tingkat kekerasan kulit. Serangga membutuhkan nutrisi dalam bentuk karbohidrat, protein, lemak, sterol, vitamin, asam nukleat, air, dan mineral. Protein merupakan unsur essensial yang dibutuhkan oleh imago serangga betina untuk produksi telur. Kadar protein pada beras Pulo Aceh sebesar $1,563 \%$, beras Tajuk sebesar $0,926 \%$, beras Toa sebesar $0,681 \%$, beras Bontok sebesar $0,555 \%$, beras Putih sebesar $0,440 \%$, dan beras Depet sebesar 0,408\%. Kandungan nutrisi pada beras Pulo Aceh, Tajuk, dan Toa memiliki peranan dalam peningkatan populasi S. oryzae

\section{Median Waktu Perkembangan S. oryzae}

Hasil analisis ragam menunjukkan bahwa jenis beras asal padi lokal dataran tinggi Aceh berpengaruh sangat nyata terhadap median waktu perkembangan hama S. oryzae $(F=8,06 ; d b=5$; dan $P<0,0015)$. Median waktu perkembangan $S$. oryzae paling lama dijumpai pada beras Depet yaitu 49 hari. Median waktu perkembangan paling singkat dijumpai pada beras Pulo Aceh yaitu 32,67 hari yang tidak berbeda nyata dengan beras Putih, Tajuk, Bontok, dan Toa. Median waktu perkembangan paling lama dijumpai pada beras Depet yaitu 49 hari (Tabel 3). Median waktu perkembangan dan jumlah turunan pertama S. oryzae merupakan parameter yang penting untuk menentukan kerentanan beras dari padi lokal dataran tinggi Aceh terhadap $S$. oryzae. Median waktu perkembangan $S$. oryzae yang lama menunjukan bahwa beras tersebut tergolong tahan, sedangkan jumlah $\mathrm{F} 1 \mathrm{~S}$. oryzae yang semakin banyak menunjukkan bahwa beras tersebut tergolong rentan terhadap S. oryzae.

\section{Persentase Beras Berlubang dan Persentase Bubuk Beras}

Hasil analisis ragam menunjukkan bahwa jenis beras asal dataran tinggi Aceh berpengaruh sangat nyata terhadap persentase beras berlubang $(F=140,37 ; d b=$ 5; dan $P<0,0001)$ dan bubuk beras $(F=$ $21,11 ; d b=5$; dan $P<0,0001)$. Hasil penelitian menunjukkan bahwa serangan $S$. oryzae pada jenis beras tersebut menyebabkan beras menjadi berlubang dan bubuk. Persentase beras berlubang dan bubuk beras merupakan parameter dalam melihat tingkat kerusakan dalam bahan pangan seperti besar akibat serangan hama $S$. oryzae. Persentase beras berlubang paling tinggi dijumpai pada beras Pulo Aceh sebesar $31,33 \%$ dan berbeda nyata dibandingkan dengan jenis beras lainnya. Persentase beras berlubang paling rendah dijumpai pada Depet sebesar $6,33 \%$ dan berbeda nyata dengan jenis beras lainnya. Beras Bontok dan Toa memiliki persentase beras berlubang yang tidak berbeda nyata. Persentase bubuk beras paling banyak dijumpai pada beras Pulo Aceh sebesar $2,51 \%$ dan tidak berbeda nyata dibandingkan dengan beras Tajuk. Persentase bubuk beras paling sedikit diketahui pada beras Depet yaitu 0,18\% dan berbeda nyata dengan jenis beras lainnya. Beras Toa dan Bontok memiliki persentase bubuk beras yang tidak berbeda nyata (Tabel 3). Hama S. oryzae tergolong sebagai hama primer yang merusak biji utuh seperti beras. Serangan $S$. oryzae menyebabkan kerusakan pada beras yang gejalanya dapat terlihat antara lain dengan adanya lubang gerek, lubang keluar, bubuk dan kontaminasi beras dari kotoran. Serangga dewasa dan larva $S$. oryzae merusak bahan pangan dengan memakan karbohidrat dalam butiran biji sehingga terjadi penurunan susut berat pangan dan kontaminasi produk, mengurangi viabilitas benih, menurunkan nilai pasar, dan 
Tabel 2. Populasi S. oryzae pada beras dataran tinggi Aceh

\begin{tabular}{|c|c|c|c|c|c|c|c|c|}
\hline \multirow{2}{*}{ Jenis beras } & \multicolumn{8}{|c|}{ Populasi S. oryzae (imago/250 g) } \\
\hline & $36 \mathrm{HSI}$ & $43 \mathrm{HSI}$ & $50 \mathrm{HSI}$ & 57 HSI & 64 HSI & $71 \mathrm{HSI}$ & $78 \mathrm{HSI}$ & $85 \mathrm{HSI}$ \\
\hline Putih & $31,67 \mathrm{bc}$ & $71 \mathrm{c}$ & $98,67 \mathrm{bc}$ & $109,33 \mathrm{c}$ & $111,33 \mathrm{c}$ & $119 \mathrm{~b}$ & $124,33 \mathrm{~b}$ & $127,33 \mathrm{~cd}$ \\
\hline Tajuk & 43,6 & 198,33 a & $272,33 \mathrm{a}$ & $301,33 a b$ & 318 & 375,33 a & 399 a & $434,33 \mathrm{~b}$ \\
\hline Bontok & $36,33 b$ & $113,33 \mathrm{bc}$ & $116,33 a b$ & $189,33 \mathrm{abc}$ & 200 bc & $209,33 \mathrm{~b}$ & $219,67 b$ & $223 \mathrm{c}$ \\
\hline Depet & $22 \mathrm{c}$ & $27 d$ & $30,33 \mathrm{c}$ & $31,33 \mathrm{~d}$ & $32,67 \mathrm{~d}$ & $37,67 \mathrm{c}$ & $43,67 \mathrm{c}$ & $47 \mathrm{~d}$ \\
\hline Pulo Aceh & $36 \mathrm{~b}$ & $136,33 \mathrm{~b}$ & $242 \mathrm{a}$ & $341 \mathrm{a}$ & $403,67 \mathrm{a}$ & 509 a & 571 a & 680,33 a \\
\hline Toa & $63,33 \mathrm{a}$ & $127 b$ & $146,33 a b$ & $163,33 \mathrm{bc}$ & $166,33 \mathrm{c}$ & $171,67 b$ & $180,33 \mathrm{~b}$ & $232,67 \mathrm{c}$ \\
\hline
\end{tabular}

Keterangan: angka yang diikuti oleh huruf yang sama pada kolom yang sama tidak berbeda nyata berdasarkan uji DMRT pada taraf 0,05. HSI: hari setelah infestasi

Tabel 3. Parameter median waktu perkembangan S. oryzae, kerusakan beras, dan indeks kerentanan berbagai jenis beras asal dataran tinggi Aceh terhadap S. oryzae

\begin{tabular}{|c|c|c|c|c|c|}
\hline Jenis beras & $\begin{array}{c}\text { Median waktu } \\
\text { perkembangan } \\
\text { (hari) }\end{array}$ & $\begin{array}{c}\text { Persentase beras } \\
\text { berlubang }\end{array}$ & $\begin{array}{l}\text { Persentase } \\
\text { bubuk beras }\end{array}$ & $\begin{array}{c}\text { Indeks } \\
\text { kerentanan }\end{array}$ & $\begin{array}{l}\text { Katagori } \\
\text { kerentanan }\end{array}$ \\
\hline Putih & $36,33 \mathrm{~b}$ & $10,67 \mathrm{~d}$ & $0,53 \mathrm{c}$ & $5,35 \mathrm{~b}$ & Moderat \\
\hline Tajuk & $34 \mathrm{~b}$ & $23,67 b$ & $1,87 \mathrm{a}$ & $7,14 \mathrm{a}$ & Moderat-rentan \\
\hline Bontok & $34 b$ & $16,33 \mathrm{c}$ & $1,03 \mathrm{~b}$ & $6,52 \mathrm{ab}$ & Moderat \\
\hline Depet & $49 a$ & $6,33 \mathrm{e}$ & $0,18 d$ & $2,18 \mathrm{c}$ & Resisten \\
\hline Pulo Aceh & $32,67 b$ & $31,33 \mathrm{a}$ & $2,51 \mathrm{a}$ & $7,10 \mathrm{a}$ & Moderat-rentan \\
\hline Toa & $35 \mathrm{~b}$ & $18,67 \mathrm{c}$ & $1,10 b$ & $6,56 a b$ & Moderat \\
\hline
\end{tabular}

Keterangan: angka yang diikuti oleh huruf yang sama pada kolom yang sama tidak berbeda nyata berdasarkan uji DMRT pada taraf 0,05.

mengurangi nilai gizi (Ashamo, 2006). Bubuk beras merupakan fraksi bubuk yang terbentuk dari hancuran beras yang menjadi rapuh selama penyimpanan akibat konsumsi beras oleh S. oryzae. Pembentukan bubuk beras membuat beras menjadi rusak dan tidak dapat dikonsumsi (Hendrival \& Meutia, 2016; Hendrival \& Melinda, 2017). Bubuk beras berkaitan erat dengan aktivitas makan serangga $S$. oryzae dalam memilih makanan yang memiliki kandungan gizi yang tinggi.

\section{Indeks Kerentanan}

Hasil analisis ragam menunjukkan bahwa jenis beras dataran tinggi Aceh berpengaruh sangat nyata terhadap indeks kerentanan $(F=21,46 ; d b=5$; dan $P<$ $0,0001)$. Nilai indeks kerentanan beras lokal dataran tinggi Aceh berkisar antara 2,18 sampai 7,14 . Indeks kerentanan paling rendah dijumpai pada beras Depet sebesar 2,18 dan berbeda nyata dengan jenis beras lainnya, sedangkan nilai indeks kerentanan paling tinggi dijumpai pada beras Pulo Aceh sebesar 7,14 dan tidak berbeda nyata dengan beras Tajuk, Toa, dan Bontok (Tabel 3). Berdasarkan nilai indeks kerentanan diketahui bahwa beras Depet tergolong katagori resisten, sedangkan beras Putih, Toa, dan Bontok tergolong katagori moderat. Beras Tajuk dan Pulo Aceh tergolong katagori moderat sampai rentan terhadap serangan hama $S$. oryzae selama penyimpanan. Nilai indeks kerentanan yang tinggi menggambarkan beras tersebut semakin rentan sedangkan nilai indeks kerentanan yang rendah maka beras tersebut semakin resisten terhadap S. oryzae.

Hasil analisis korelasi menunjukkan bahwa terdapat korelasi positif yang sangat nyata antara indeks kerentanan beras dataran tinggi Aceh dengan kadar air, korelasi positif yang tidak nyata dengan kadar abu, lemak, dan protein serta terdapat korelasi negatif yang tidak nyata dengan kadar serat dan karbohidrat beras asal dataran tinggi Aceh. Korelasi antar karakter ini menunjukkan bahwa peningkatan nilai indeks kerentanan dipengaruhi oleh peningkatan kadar air $(r=$ $\left.0,864^{*} ; P<0,05\right)$ dan tidak dipengaruhi oleh kadar protein $(r=0,587 ; P>0,01)$ serta karbohidrat $(r=-0,415 ; P>0,01)$ (Tabel 4). Kadar air beras yang tinggi menyebabkan beras menjadi rentan terhadap serangan $S$. oryzae. Sifat kimia beras seperti kadar air merupakan sumber ketahanan beras dataran tinggi Aceh terhadap serangan hama $S$. oryzae. Sifat kimia beras sebagai sumber ketahanan terhadap hama $S$. oryzae tergolong sebagai ketahanan antibiosis. Sumber ketahanan bahan pangan di penyimpanan terhadap infestasi serangga hama pascapanen adalah antibiosis dan antisenosis (Derera et al., 2001a, 2001b; Reddy et al., 2002). Ketahanan antibiosis memiliki kemampuan mengurangi proses metabolisme, meningkatkan kegelisahan, dan kematian pada larva atau imago (Derera et al., 2001a). 
Tabel 4. Matriks korelasi antara dimensi beras, kadar air, kadar protein, kadar karbohidrat, jumlah F1 S. oryzae, median waktu perkembangan S. oryzae, persentase beras berlubang, dan persentase bubuk beras terhadap kerentanan beras dataran tinggi Aceh

\begin{tabular}{|c|c|c|c|c|c|c|c|c|c|c|c|}
\hline Karakter & $\begin{array}{l}\text { Panjang } \\
\text { beras }\end{array}$ & $\begin{array}{l}\text { Lebar } \\
\text { beras }\end{array}$ & $\begin{array}{l}\text { Rasio } \\
\text { beras }\end{array}$ & Kadar air & Protein & Karbohidrat & $\begin{array}{c}\text { Jumlah F1 } \\
\text { S. oryzae }\end{array}$ & $\begin{array}{c}\text { Persentase } \\
\text { beras } \\
\text { berlubang }\end{array}$ & $\begin{array}{l}\text { Persentase } \\
\text { bubuk beras }\end{array}$ & $\begin{array}{l}\text { Median waktu } \\
\text { perkembangan }\end{array}$ & $\begin{array}{l}\text { Indeks } \\
\text { kerentanan }\end{array}$ \\
\hline Panjang beras & 1 & & & & & & & & & & \\
\hline Lebar beras & 0,327 tn & 1 & & & & & & & & & \\
\hline Rasio beras & $0,988^{\star *}$ & 0,179 tn & 1 & & & & & & & & \\
\hline Kadar air & 0,024 tn & $-0,454$ tn & 0,107 tn & 1 & & & & & & & \\
\hline Protein & 0,316 th & 0,419 tn & 0,419 tn & $0,774^{*}$ & 1 & & & & & & \\
\hline Karbohidrat & $-0,072 \mathrm{tn}$ & $-0,101 \mathrm{tn}$ & $-0,101 \mathrm{tn}$ & $-0,699$ tn & $0,771^{*}$ & 1 & & & & & \\
\hline Jumlah F1 S. oryzae & 0,371 tn & 0,453 tn & 0,453 tn & $0,928^{* *}$ & $0,884^{* *}$ & $-0,692$ tn & 1 & & & & \\
\hline $\begin{array}{l}\text { Persentase beras } \\
\text { berlubang }\end{array}$ & 0,409 tn & 0,506 tn & 0,506 tn & $0,872^{*}$ & $0,945^{\star *}$ & 0,676 tn & $0,981^{* *}$ & 1 & & & \\
\hline $\begin{array}{l}\text { Persentase bubuk } \\
\text { beras }\end{array}$ & 0,316 tn & 0,412 tn & 0,412 tn & $0,912^{* *}$ & $0,951^{* *}$ & $-0,743 \operatorname{tn}$ & $0,983^{* *}$ & $0,992^{* *}$ & 1 & & \\
\hline $\begin{array}{l}\text { Median waktu } \\
\text { perkembangan }\end{array}$ & 0,039 tn & $-0,005 \mathrm{tn}$ & $-0,005 \mathrm{tn}$ & $-0,705$ tn & $-0,351$ tn & 0,190 tn & $-0,645 \mathrm{tn}$ & $-0,555 \mathrm{tn}$ & $-0,562$ tn & 1 & \\
\hline Indeks kerentanan & 0,106 tn & $-0,339$ tn & 0,167 tn & $0,864^{*}$ & $0,587 \mathrm{tn}$ & $-0,415$ tn & $0,843^{*}$ & $0,768^{*}$ & 0,777 tn & $-0,954^{\star *}$ & 1 \\
\hline
\end{tabular}

\section{Keterangan:}

** berkorelasi sangat nyata $(P<0,01)$ dan * berkorelasi nyata $(P<0,05)$ 
Hasil analisis korelasi juga menunjukkan bahwa terdapat korelasi positif yang tidak nyata antara indeks kerentanan dengan karakteristik dimensi beras seperti panjang beras $(r=0,106 ; P>0,01)$, korelasi negatif yang tidak nyata dengan lebar beras $(r=-$ $0,339 ; P>0,01)$, serta korelasi positif yang tidak nyata dengan rasio beras $(r=0,167 ; P>$ 0,01) (Tabel 4). Karakteristik dimensi beras bukan merupakan sumber ketahanan beras lokal dataran tinggi Aceh terhadap S. oryzae. Imago betina $S$. oryzae tidak memilih beras berdasarkan dimensi karena imago tidak dapat memperkirakan dengan pasti dimensi beras. Trematerra et al. (2004) mengemukakan bahwa hama $S$. zeamais lebih menyukai bulir padi yang yang berukuran besar, hal ini diduga kuat berkaitan dengan dimensi ukuran tubuhnya.

Hasil analisis korelasi menunjukkan bahwa terdapat korelasi positif yang nyata antara indeks kerentanan dengan jumlah $\mathrm{F} 1 \mathrm{~S}$. oryzae $\left(r=0,843^{\star} ; P<0,05\right)$ dan korelasi negatif yang sangat nyata dengan median waktu perkembangan $S$. oryzae $\left(r=-0,954^{* *}\right.$; $P<0,01$ ). Korelasi antar karakter menjelaskan bahwa kerentanan beras dataran tinggi Aceh ditentukan oleh jumlah $\mathrm{F} 1$ dan median waktu perkembangan $S$. oryzae. Jumlah $\mathrm{F} 1 \mathrm{~S}$. oryzae yang banyak dan median waktu perkembangan yang singkat dapat menyebabkan beras menjadi rentan terhadap serangan hama $S$. oryzae. Hasil yang sama juga dikemukakan oleh Rini \& Hendrival (2017) yaitu kerentanan beras asal padi gogo lokal Jambi dipengaruhi oleh jumlah F1 dan median waktu perkembangan $S$. oryzae.

Kandungan protein dan kadar air dari beras memiliki korelasi positif terhadap populasi imago $S$. oryzae, persentase beras berlubang, dan persentase bubuk beras. Korelasi antar karakter ini menunjukkan bahwa perbedaan kadar air dan protein beras dataran tinggi Aceh dapat meningkat populasi imago $S$. oryzae (kadar air: $r=0,928^{* *}$; protein: $r=$ $0,884^{* *} P<0,01$ ), persentase beras berlubang (kadar air: $r=0,872^{*} P<0,05$; protein: $r=$ $0,945^{\star *} P<0,01$ ), dan persentase bubuk beras (kadar air: $r=0,912^{* *}$; protein: $r=$ $0,951^{* *} P<0,01$ ) selama penyimpanan (Tabel 4). Korelasi positif yang sama juga dilaporkan oleh Caneppele et al. (2003) antara jumlah serangga $S$. zeamais dengan kadar air jagung. Hasil penelitian Mboya (2013) menunjukkan bahwa terdapat korelasi positif antara kadar air serealia saat panen dengan kepadatan populasi serangga selama penyimpanan. Kadar air yang tinggi pada beras menyebabkan tekstur dari beras menjadi lebih lunak yang akan mempermudah larva dan imago $S$. oryzae untuk merusak beras dan perkembangan progenisnya (Lopulalan, 2010). Pengetahuan pertumbuhan populasi imago $S$. oryzae dan karakteristik kehilangan bobot pada beras dapat dimanfaatkan sebagai acuan bagi masyarakat untuk tidak menyimpan beras untuk keperluan konsumsi yang mudah diserang oleh hama $S$. oryzae dalam jumlah yang banyak dan jangka waktu yang lama.

\section{KESIMPULAN DAN SARAN}

Beras asal padi lokal dataran tinggi Aceh memiliki tingkat ketahanan dari resisten sampai moderat-rentan terhadap infestasi hama $S$. oryzae. Beras Depet tergolong katagori resisten, sedangkan beras Putih, Toa, dan Bontok tergolong katagori moderat. Beras Tajuk dan Pulo Aceh tergolong katagori moderat sampai rentan terhadap serangan hama $S$. oryzae selama penyimpanan. Beras Tajuk dan Pulo Aceh tidak dapat disimpan dalam jangka waktu yang lama, sedangkan beras Depet dapat dijadikan sumber aksesi untuk merakit varietas padi yang tahan terhadap serangan hama $S$. oryzae.

\section{UCAPAN TERIMAKASIH}

Penelitian ini dibiayai oleh Direktorat Riset dan Pengabdian kepada Masyarakat (DRPM) Kemenristekdikti RI melalui Penelitian Dosen Pemula tahun 2016 dari Lembaga Penelitian dan Pengabdian kepada Masyarakat Universitas Malikussaleh.

\section{DAFTAR PUSTAKA}

Adarkwah, C., D. Obeng-Ofori, C. Büttner, C. Reichmuth, and M. Schöller. 2012. Potential of Lariophagus distinguendus (Förster) (Hymenoptera: Pteromalidae) to suppress the maize weevil Sitophilus zeamais Motschulsky (Coleoptera: Curculionidae) in bagged and bulk stored maize. Biological Control 60, 175-181.

DOl: 10.1016/j.biocontrol.2011.11.003

Anggara, A.W. dan Sudarmaji. 2008. Hama pascapanen padi dan pengendaliannya. Di dalam: Darajat, AA., Setyono, A. Makarim, A.K., dan Hasanuddin, A. (Editor). Padi: Inovasi Teknologi Produksi. Balai Besar Penelitian Tanaman Padi. Jakarta. LIPI Press. hIm: 441-472.

Ashamo, M.O. 2006. Relative susceptibility of some local \& elite rice varieties to the rice weevil, Sitophilus oryzae L. (Coleoptera: Curculionidae). Journal of 
Food, Agriculture and Environment, 4(1): 249-252.

Association of Official Analytical Chemist [AOAC]. 2005. Official Methods of Analysis. Association of Official Analytical Chemist Inc. Mayland. USA.

Bergvinson, D. and S. Garcia-Lara. 2004. Genetic approaches to reducing losses of stored grain to insects and diseases. Current Opinion Plant Biology, 7: 480485. DOI: 10.1016/j.pbi.2004.05.001

Caneppele, M.A.B., C. Caneppele, F.A. Lázzari, and S.M.N. Lázzari. 2003. Correlation between the infestation level of Sitophilus zeamais Motschulsky, 1855 (Coleoptera, Curculionidae) and the quality factors of stored corn, Zea mays L. (Poaceae). Revista Brasileira de Entomologia 47, (4): 625-630.

Derera, J., K.V. Pixley, and P.D. Giga. 2001a. Resistance of maize to the maize weevil: I-Antibiosis. African Crop Science Journal, 9(2): 431-440.

Derera, J., P.D. Giga, and K.V. Pixley. 2001b. Resistance of maize to the maize weevil: II-Non preference. African Crop Science Journal, 9(2): 441-450.

Derera, J., K.V. Pixley, D.P. Giga, and I. Makanda. 2014. Resistance of maize to the maize weevil: III. Grain weight loss assessment and implications for breeding. Journal of Stored Products Research, 59: 24-35. DOI: 10.1016/j.jspr.2014.04.004

Dobie, P. 1974. The laboratory assessment of the inherent susceptibility of maize varieties to post harvest infestation by Sitophilus zeamais Motsch. (Coleoptera: Curculionidae) infesting field corn. Journal of Entomology Science, 21: 367-375.

Gbaye, O.A. and B.A. Olanrewaju. 2016. Susceptibility level of some Nigerian hybrid and local rice varieties to Sitophilus oryzae L. (Coleoptera: Curculionidae). International Journal of Entomology Research, 1(2): 10-13.

Hendrival dan R. Meutia. 2016. Pengaruh periode penyimpanan beras terhadap pertumbuhan populasi Sitophilus oryzae (L.) dan kerusakan beras. Biogenesis, 4(2): 95-101.

DOI:10.24252/bio.v4i2.2514

Hendrival dan L. Melinda. 2017. Pengaruh kepadatan populasi Sitophilus oryzae (L.) terhadap pertumbuhan populasi dan kerusakan beras. Biospecies, 10(1): 1724.

Indrasari, S.D., E.Y. Purwani, S. Widowati, dan D.S. Damardjati. 2008. Peningkatan nilai tambah beras melalui mutu fisik, cita rasa, dan gizi. Di dalam: Darajat, AA., Setyono, A. Makarim, A.K., dan Hasanuddin, A. (Editor). Padi: Inovasi Teknologi Produksi. Balai Besar Penelitian Tanaman Padi. Jakarta. LIPI Press. hlm: 565-590.

Kalshoven, L.G.E. 1981. Pests of Crops in Indonesia. PT. Ichtiar Baru-van Hoeve. Jakarta.

Longstaff, B.C. 1981. Biology of the grain pest species of the genus Sitophilus (Coleoptera: Curculionidae): a critical review. Protection Ecology, 2: 82-130.

Lopulalan, C.G.C. 2010. Analisa ketahanan beberapa varietas padi terhadap serangan hama gudang (Sitophilus zeamais Motschulsky). Jurnal Budidaya Pertanian, 6(1): 11-16.

Mboya, R.M. 2013. An investigation of the extent of infestation of stored maize by insect pests in Rungwe District, Tanzania. Food Security, 5: 525-531. DOI: 10.1007/s12571-013-0279-3

Nesci, A., P. Barra, and M. Etcheverry. 2011. Integrated management of insect vectors of Aspergillus flavus in stored maize, using synthetic antioxidants and natural phytochemicals. Journal of Stored Products Research, 47: 231237. DOI: 10.1016/j.jspr.2011.03.003

Reddy, K.P.K., B.U. Singh, and R. Dharma. 2002. Sorghum resistance to the rice weevil, Sitophilus oryzae (L.): antixenosis. International Journal of Tropical Insect Science, 22(1): 9-19.

Rini, S.F. dan Hendrival. 2017. Kajian Kerentanan beras dari padi gogo lokal Jambi terhadap Sitophilus oryzae L. (Coleoptera: Curculionidae). Biogenesis, 5(1): 13-20. DOI: 10.24252/bio.v4i2.3428

Trematerra, P., M.C.Z. Paula, A. Sciarretta, and S.M.N. Lazzari. 2004. Spatiotemporal analysis of insect pests infesting a paddy rice storage facility. Neotropical Entomology, 33(4): 469-479.

Zakka, U., N.E.S. Lale, and O.C. Umeozor. 2015. Efficacy of combining varietal resistance with harvest time and planting date for the management of Sitophilus zeamais Motschulsky infestation in stored maize. Journal of Stored Products Research, 60: 31-35. DOI: 10.1016/j.jspr.2014.10.005

Zunjare, R., F. Hossain, V. Muthusamy, S.K. Jha, P. Kumar, J.C. Sekhar, N. Thirunavukkarasu, and H.S. Gupta. 2016. Genetic variability among exotic 
Jurnal Agroteknologi, Vol. 8 No. 2, Februari 2018: 21 - 30

and indigenous maize inbreds for resistance to stored grain weevil (Sitophilus oryzae L.) infestation. Cogent Food and Agriculture, 2: 1-10. DOI:10.1080/23311932.2015.1137156 
Kerentanan Beras Asal Padi Lokal Dataran Tinggi Aceh terhadap (Hendrival, dkk) 